\title{
COMPARATIVE STUDY ON DEGRADATION OF POLYLACTIC ACID/ SYZYGIUM AROMATICUM COMPOSITES AGEING IN OUTDOOR ENVIRONMENT AND SOIL BURIAL
}

\author{
Salina Budin*, Normariah Che Maideen, Koay Mei Hyie, \\ HAMID YUSSOF AND HALIM GHAFAR \\ School of Mechanical Engineering, College of Engineering, Universiti Teknologi MARA, \\ Cawangan Pulau Pinang, Jalan Permatang Pauh, 13500 Penang, Malaysia \\ *Corresponding author: salinabudin@uitm.edu.my
}

(Received: $28^{\text {th }}$ July 2021; Accepted: $24^{\text {th }}$ September 2021; Published on-line: $4^{\text {th }}$ January 2022)

\begin{abstract}
Major environmental problems resulting from non-degradable components of plastic wastes have awakened great attention to bioplastic as an alternative material. Among various bioplastic materials, polylactic acid (PLA) is recognised as a promising material especially as a food packaging material. The development of PLA composites using various fillers has extensively been in focus in order to preserve the high quality, safety, and extended shelf-life of packed food. Among the interesting fillers is Syzygium aromaticum (SA). SA, also known as clove, has biological activities such as antibacterial, antifungal, insecticidal, and antioxidant properties. This work investigated the effects of SA filler on the degradations of virgin PLA (VPLA) and recycled PLA (RPLA). The VPLA/SA composites and RPLA/SA composites were prepared using the solvent casting method. The content of SA filler varied in the range of 0 to $20 \mathrm{wt} \%$. The composites were aged in outdoor environment and soil burial. The results revealed that the degradation rate was increased with the increase of SA filler in both ageing environments. After 10 weeks of ageing in the outdoor environment, the weight loss of VPLA/SA composites and RPLA/SA composites containing $20 \mathrm{wt} \%$ of SA were $7.7 \%$ and $12.8 \%$ respectively. Whereas in soil burial, the weight loss of VPLA/SA composites and RPLA/SA composites with similar SA content were $25.6 \%$ and $38.3 \%$ respectively. The degradation rate was observed to be more rapid in the soil burial as compared to the outdoor environment. Comparably, RPLA and RPLA/SA composites experienced higher degradation rates than VPLA and VPLA/SA composites. The degradation rate was consistent with scanning electron microscope (SEM) images which observed the formation of holes, cavities, cleavages, and grooves on the surfaces of the samples. Thermogravimetric analysis (TGA) results on aged samples showed that VPLA/SA composites and RPLA/SA composites that had aged in soil burial decomposed at lower temperatures. The shortening of degradation time of the VPLA/SA composites and RPLA/SA composites could increase their potential to be used as food packaging materials.
\end{abstract}

ABSTRAK: Masalah utama terhadap alam sekitar yang disebabkan oleh sisa plastik yang sukar terurai, telah menarik perhatian terhadap bioplastik sebagai bahan alternatif. Di antara pelbagai jenis bahan bioplastik sedia ada, asid polilaktik(PLA) dilihat sebagai bahan yang paling sesuai terutamanya sebagai bahan pembungkusan makanan. Perkembangan di dalam penghasilan komposit asid polilaktik yang ditambah dengan pelbagai bahan pengisi telah menjadi fokus terutamanya bagi tujuan meningkatkan kualiti, kesegaran dan jangka hayat makanan. Salah satu pengisi yang mendapat perhatian adalah Syzygium aromaticum (SA). SA yang juga dikenali sebagai bunga cengkeh mempunyai aktiviti biologi, seperti sifat antibakteria, antijamur, racun serangga dan antioksidan yang tinggi. Didalam kajian 
ini, siasatan terhadap kesan penambahan SA terhadap penguraian PLA asal (VPLA) dan PLA kitar semula (VPLA). Komposit VPLA/SA dan komposit RPLA/SA disediakan dengan menggunakan kaedah pelarutan pelarut. Kandungan pengisi SA adalah didalam julat $0-20 \%$ mengikut berat. Komposit tersebut dibiarkan menua didalam persekitaran luaran dan didalam tanah. Keputusan kajian mendapati bahawa kadar penguraian semakin meningkat dengan penambahan peratus berat bahan pengisi SA setelah melalui penuaan didalam kedua-dua persekitaran. Setelah penuaan selama10 minggu di dalam persekiran luaran, pengurang berat komposit VPLA/SA dan komposit RPLA/SA yang mengandungi $20 \mathrm{wt} \%$ SA adalah $7.7 \%$ dan $12.8 \%$. Manakala bagi penuaan didalam tanah, pengurangan berat komposit VPLA/SA dan komposit RPLA/SA dengan kandungan SA yang sama masing-masing adalah $25.6 \%$ dan $38.3 \%$. Kadar penguraian diperhatikan lebih cepat bagi penuan didalam tanah dibandingkan dengan penuaan didalam persekitaran luaran. Disamping itu, RPLA dan komposit RPLA/SA mengalami kadar penguraian yang lebih tinggi berbanding VPLA dan komposit VPLA/SA. Kadar penguraian adalah konsisten dengan imej yang dihasilkan oleh imbasan mikroskop elektron (SEM) dimana dapat dilihat pembentukan lubang, rongga, pembelahan dan alur di permukaan sampel. Hasil analisis termogravimetri (TGA) terhadap sampel yang telah dituakan menunjukkan bahawa komposit VPLA/SA dan komposit RPLA/SA yang melalui penuaan didalam tanah terurai pada suhu yang lebih rendah. Tempoh penguraian komposit VPLA/SA dan komposit RPLA/SA yang lebih pendek ini meningkatkan potensi penggunaannya komposit ini sebagai bahan pembungkusan makanan.

KEYWORDS: degradation; virgin PLA; recycled PLA; outdoor environment; soil burial

\section{INTRODUCTION}

Huge employment of plastic materials in various fields is derived from its excellent properties such as its light weight, flexibility, strength, transparency, permeability, and costeffectiveness [1]. Approximately $50 \%$ of plastics are used for single-use disposable applications, such as packaging, agricultural films, and disposable consumer items [2]. These have led to the continuous generation of bulk plastic wastes that have ended with environmental and marine issues. It has been reported that at least 180 kinds of marine organisms have been detected consuming plastics by mistake ranging from whales to planktons [3]. Most commercial plastics are non-biodegradable, highly resistant to microbial attacks, and require a longer time to degrade, which will be approximately around 10 to 1000 years. The issue related to plastic waste management and its disposal is seen to be the main inspiration for the commercialisation of bioplastics. Bioplastics are plastics materials produced from renewable biomass sources, such as vegetable fats and oils, corn starch, straw, woodchips, sawdust, and recycled food waste. Various bioplastic materials are available such as polyhydroxy-alkanoates (PHA) and poly-3-hydroxybutyrate (PHB). Among these, polylactic acid (PLA) is the most popular bioplastic which has higher potential in replacing fossil-based commercial plastic. PLA is biobased and easily compostable with a relatively higher production produced by fermentation from renewable substrates such as sugar, starch, sugarcane, corn, beets, rice, and carbohydrates from other crops $[4,5]$. As a bioplastic material, PLA completely decomposes to $\mathrm{CO}_{2}$ and $\mathrm{H}_{2} \mathrm{O}$ as final degradation products without contributing any harmful effects to the environment. Moreover, it was reported that PLA will take at least 2 years to be fully degraded under normal circumstances [3].

Both the chemical and physical properties of PLA influence the mechanisms of biodegradation. The surface area, hydrophilic or hydrophobic properties, chemical structure, molecular weight, glass transition temperature, melting temperature, modulus of elasticity, crystallinity, and crystal structure of polymers play important roles in the biodegradation 
processes [6]. Degradation of PLA is primarily due to the hydrolysis of the ester linkages which occurs more or less randomly along the backbone of the polymer. In the presence of water, the hydrolysis takes place via a diffusion reaction mechanism whereby water penetrates the polymer matrix and simultaneously converts the long polymer chain to low molecular weight, water soluble oligomers, and finally the given monomer [7]. It is noteworthy that under UV irradiation and light exposure, the hydrolysis of the PLA molecular chain is accomplished through photocleavage, photolysis, and photooxidation [8]. Photolysis leads to chain scission especially in the $\mathrm{C}-\mathrm{O}$ bonds of the PLA ester backbone structure through the absorption of a photon while photocleavage takes place at the ester group and ethylidene group next to the ester oxygen in the PLA structure leading to chain cleavage and the formation of $\mathrm{C}=\mathrm{C}$ double bonds and carboxylic acid $-\mathrm{OH}$ stretching. Photooxidation of PLA results in the formation of hydroperoxide derivative and its subsequent degradation into carboxylic acid and diketone end groups [9]. The presence of moisture in the environment would further promote the hydrolysis degradation of PLA.

PLA has been recognised by the United States Food and Drug Administration (FDA) as a safe material for food packaging [10]. However, brittleness, low heat distortion temperature, and poor antioxidant, antibacterial, and barrier properties have only limited its application [11]. In order to have high quality, safe packaging and extend the shelf-life of packed food, the packaging material must be able to reduce or retard the growth of microorganisms and inhibit the process of lipid oxidation [12]. The addition of antibacterial and antioxidant agents in PLA substrate is one of the rational solutions. Moreover, the addition of filler in PLA substrate would also accelerate the degradation and decomposition of the PLA. A higher degradation rate would assist in accelerating PLA waste degradation, especially for single-use products. Several efforts have been devoted to the modifications of PLA by incorporating various fillers in order to improve those properties. Many studies on fillers reacted as antioxidant, antimicrobial, antibacterial, and degradation accelerator agents have been conducted with fillers such as chitosan, cinnamaldehyde, Syzygium aromaticum (clove), Melissa officinalis L. (lemon balm), Salvia officinalis (sage), zinc oxide $(\mathrm{ZnO})$, titanium oxide $(\mathrm{TiO})$, magnesium oxide $(\mathrm{MgO})$ and calcium carbonate [13-17].

Besides that, past research has been investigated globally in order to improve the desirable properties for food packaging applications. Zhang et al. [18] synthesised PLA/cinnamaldehyde (CA) films. The findings proved that the morphology, crystallinity, oxygen resistance, water resistance, and tensile strength properties were improved. The antibacterial activity against Escherichia coli and Monocytogenes was $100 \%$. Similar results were also published by Cui et al. [19]. On the other hand, Ahmed et al. [11] developed PLA/ PEG/PCL films loaded with $\mathrm{ZnO}$ and SA/clove essential oil (CEO). The results showed that the reinforcement of $\mathrm{ZnO}$ and $\mathrm{CEO}$ were significant in the mechanical properties and structural and barrier properties of the films. Meanwhile, Chen et al. [12] investigated the effects of polyvinyl alcohol (PVA) film with an addition of clove oil (CO). It was concluded that the incorporation of CO in PVA films had demonstrated effective antimicrobial and antioxidant activities. However, the mechanical properties, oxygen barrier properties, and thermal stability of the films were reduced.

Techawinyutham et al. [20] also reported on the improvement of tensile properties and antibacterial activity with the addition of capsicum oleoresin impregnated porous silica (SiCO). The authors have remarked that the tensile properties, thermal stability, and rheological properties were reduced when the films underwent ageing in accelerated weathering for 520 hours. However, the aged samples showed good antimicrobial activity against bacteria. In other research done by Varsavas and Kaynak [21], the mechanical properties of neat PLA and PLA/glass fibre composite (PLA/GF) under outdoor conditions 
were evaluated. The samples were exposed to accelerated weathering conditions of both UV-irradiation and moisture cycles. The authors observed that the decreased in mechanical properties of neat PLA was more significant as compared to PLA/GF composite. After 400 hours of ageing, the reduction in the tensile strength of the neat PLA specimen was as much as $92 \%$, while the reduction for the PLA/GF specimen was only $34 \%$.

In other works, Fathima et al. [22] have developed PLA/chitosan films to evaluate the antimicrobial activity of the films against $E$. coli and Listeria monocytogenes. The results revealed that incorporation of chitosan in PLA was capable of producing packaging films with good mechanical, barrier, and antimicrobial properties. On the other hand, Hadidi et al. [23] reported that PLA composites with chitosan nanoparticles encapsulated with clove essential oil exhibited higher antioxidant activity as compared to unencapsulated chitosan nanoparticles. Similar results were supported by Han et al. [24], which observed that there was a significant improvement in the antibacterial activity of the films against $E$-coli. The authors also reported on the degradation rate of PLA/chitosan films ageing in buffer solutions at $0.01 \mathrm{M}, \mathrm{pH} 7.4$ and $37{ }^{\circ} \mathrm{C}$ for 12 weeks. The degradation rate increased as the amount of chitosan increased. The weight loss of PLA/CS films was expected to reach up to nearly $45 \%$ after 3 months. Another research done by Vasile et al. [25] examined the soil burial degradation behaviour of PLA/tributyl o-acetyl citrate/chitosan (PLA/ATBC/CS) bio-composites. The results proved that there was a small loss in the samples' weight after 150 days buried in the soil. However, significant changes were reported on mechanical, thermal, and surface properties. The presence of CS increased the hydrophilicity of biocomposite surfaces and favoured the interaction with moisture, hence promoted an attack by microorganisms.

Wang et al. [26] developed PLA nanocomposite films combined with CNC-ZnO. The authors reported that the addition of CNC-ZnO in the PLA matrix improved the crystallisation ability, interaction between nanofiller and matrix, UV-shielding performance, and degradation ability. It was reported that after 110 days buried in soil, the weight loss of pure PLA and PLA/25\% CNC-ZnO were $9 \%$ and $28 \%$, respectively. Similar trends were reported by Rajesh et al. [27]. The authors reported that there was $1.26 \%$ of weight loss for neat PLA after 90 days buried in soil and $15.2 \%$ of weight loss after the PLA had been loaded with $25 \%$ of sisal fibre. In a separate study, Lv et al. [28] looked into the degradation behaviour of PLA that was blended with starch and wood flours under soil burial. The outcomes proved that the increase of starch in the PLA matrix improved the degradation rate. Comparable results were remarked by Zuo et al. [29] whereby a significant increment in weight loss was observed after adding starch to the PLA matrix.

Therefore, this research aims to study the effects of SA filler on the degradation of virgin-PLA (VPLA) and recycled-PLA (RPLA) ageing in outdoor environment and soil burial. Excellent biological properties including antioxidant, antimicrobial, antiseptic, pesticide, analgesic, and anticarcinogenic activities have positioned SA as a potential filler in PLA for various applications such as in food, sanitary, biomedical, pharmaceutical, active packaging, and cosmetics industries [23]. Although many studies have been reported on the performance of SA as antioxidant and antimicrobial agents, limited outcomes on the degradations of PLA/SA composites have been published. Thus, it is essential to investigate the degradation behaviours of PLA/SA composites under the outdoor environment and soil burial that are the common plastic waste disposal environments. The weight loss, surface morphology, and thermal stability of PLA/SA composites after 10 weeks of ageing are examined thoroughly in this study. 


\section{METHODOLOGY}

\subsection{Material}

VPLA pellets were purchased from a local supplier (Vistec Technology Services) in an injection moulding grade, 3251D Natureworks Ingeo ${ }^{\mathrm{TM}}$ (China). The pellets were cylindrical, with an average length and diameter of $3 \mathrm{~mm}$. On the contrary, RPLA was retrieved from the 1st cycle of injection moulding wastes. The wastes were mostly collected from runners and crushed using a grinding machine. The recycled ground materials were in angular shape with an average size of less than $4 \mathrm{~mm}$. The SA powder was purchased from a local hypermarket (Mydin Hypermarket). The size of the powder was in the range of 100 to $200 \mu \mathrm{m}$. The size of the powder is measured using Energy Dispersive X-Ray Analyzer (EDX).

\subsection{Sample Preparation}

PLA/SA composites were prepared through the solvent casting method at various composition contents of PLA and SA fillers. Five different combinations of blends were prepared for both virgin and recycled PLA/SA composites. The list of the composition of the samples that were prepared is summarized in Table 1. The amount of SA filler varied in the range of $0 \mathrm{wt} \%$ to $20 \mathrm{wt} \%$ in $5 \mathrm{wt} \%$ increments. The PLA resin was pre-conditioned in a drying oven at $70{ }^{\circ} \mathrm{C}$ for 12 hours to reduce the moisture content prior to use. PLA resin was then dissolved in dichloromethane (DCM). After being completely dissolved, SA filler was added to the solution. In order to obtain a homogenous PLA/SA blend, the mixture was continuously stirred using a magnetic stirrer for 30 minutes. The mixture was cast onto a glass plate and dried at room temperature for 24 hours. After drying the PLA/SA composites, the substrates were peeled off. The thickness of the PLA/SA composites substrates was in the range of 0.5 to $0.9 \mathrm{~mm}$ and was cut into $25 \times 60 \mathrm{~mm}$ sizes. For each composition, six samples were prepared.

Table 1: Sample composition

\begin{tabular}{ccccc}
\hline \multirow{2}{*}{$\begin{array}{c}\text { Sample } \\
\text { composition }\end{array}$} & \multicolumn{2}{c}{ VPLA } & \multicolumn{2}{c}{ RPLA } \\
\cline { 2 - 5 } & VPLA (wt\%) & SA (wt\%) & RPLA (wt\%) & SA (wt\%) \\
\hline 1 & 100 & 0 & 100 & 0 \\
2 & 95 & 5 & 95 & 5 \\
3 & 90 & 10 & 90 & 10 \\
4 & 85 & 15 & 85 & 15 \\
5 & 80 & 20 & 80 & 20 \\
\hline
\end{tabular}

\subsection{Ageing Condition}

The degradation of VPLA/SA composites and RPLA/SA composites was performed in outdoor environment and soil burial. Under the outdoor environment ageing, the samples were placed on the roof in order to attain optimum exposure. The geographic parameters of the test site were at the latitude of $5.4^{\circ} \mathrm{N}$, longitude of $100.4^{\circ} \mathrm{E}$, and altitude of $10 \mathrm{~m}$. The temperature and humidity were monitored weekly within the range of $24{ }^{\circ} \mathrm{C}$ to $35^{\circ} \mathrm{C}$ and $47 \%$ to $84 \%$, respectively. The average normal sun irradiation was $298.9 \mathrm{~W} / \mathrm{m}^{2}$ [30].

For soil burial ageing, the samples were buried in organic soil that was placed in a plastic container with a depth of 2 inches from the soil surface. The $\mathrm{pH}$ and the humidity of the soil were $6.8 \pm 0.5$ and $60 \pm 10 \%$, respectively. The average soil temperature was 28.5 
$\pm 1.0^{\circ} \mathrm{C}$. The soil was regularly watered with tap water to ensure the humidity of the soil was consistent.

The ageing took place for 10 weeks. The weight of the samples was measured before and after ageing using an analytical balance. After 10 weeks of ageing in the outdoor environment, the samples were subjected to a drying process in a hot oven at a temperature of $70{ }^{\circ} \mathrm{C}$ for 3 to 4 hours before the final weight was measured. For samples ageing in soil burial, the samples were dug and rinsed with tap water in order to remove adherent soil. The samples were then dried in a hot oven at a temperature of $70{ }^{\circ} \mathrm{C}$ for 24 hours prior to final weight measurement. A longer drying time was required for samples ageing in soil burial due to excessive water content in the samples. The percentage of weight loss for each sample was calculated using Eq. (1).

$$
\% \text { weight loss }=\left(w_{f}-w_{i}\right) / w_{i} \text { X } 100 \%
$$

where $\mathrm{w}_{\mathrm{i}}$ is the weight of samples before ageing, and $\mathrm{w}_{\mathrm{f}}$ is the weight of samples after ageing.

\subsection{Surface Morphology}

The surface morphology of the PLA/SA composites after ageing was observed using a Hitachi TM3030 scanning electron microscope (SEM) at a constant accelerated voltage of $15 \mathrm{kV}$. The images were captured under a magnification of $100 \mathrm{X}$.

\subsection{Thermogravimetric Analysis}

The thermal stability of PLA/SA composites was analysed using TA instrument, SDTQ600 thermogravimetric analysis (TGA). The samples were heated from $30^{\circ} \mathrm{C}$ to $600{ }^{\circ} \mathrm{C}$ at a heating rate of $10{ }^{\circ} \mathrm{C} / \mathrm{min}$ in a nitrogen environment. The flow rate of nitrogen gas was set at $20 \mathrm{ml} / \mathrm{min}$. Initial degradation temperature, $T_{i}$ and maximum degradation temperature, $\mathrm{T}_{\max }$ (which corresponded to the weight loss) were measured from the thermogram. $\mathrm{T}_{\mathrm{i}}$, is the temperature where the weight loss is started to gradually decline, whereas $T_{\max }$ is the temperature where the maximum weight loss occurred.

\section{RESULTS AND DISCUSSION}

\subsection{Weight loss}

The percentage of weight loss after ageing in outdoor environment and soil burial is summarized in Table 2. The data shows the percentage of weight loss is increased with the increment of $\mathrm{wt} \%$ of SA filler. Figure 1 represents the plots of weight loss of VPLA/SA composites and RPLA/SA composites at various contents of SA filler after 10 weeks of ageing in outdoor environment and soil burial.

In both ageing environments (outdoor environments and soil burial) it was interesting to observe that the degradation rates of VPLA/SA composites were faster than the $100 \mathrm{wt} \%$ VPLA. A similar trend was noted for RPLA/SA composites, which revealed a higher degradation rate compared with the degradation rate of $100 \mathrm{wt} \%$ RPLA. The weight loss for $100 \mathrm{wt} \%$ VPLA after ageing in outdoor environment and soil burial were $3 \%$ and $13.2 \%$ whereas for $100 \mathrm{wt} \%$ RPLA after ageing in outdoor environment and soil burial were $3.4 \%$ and $14.5 \%$. After being incorporated with $20 \mathrm{wt} \%$ of SA filler, the weight loss for VPLA/SA composites after ageing in outdoor environment and soil burial had increased to $7.7 \%$ and $25.6 \%$ respectively. 
Table 2: Weight loss after ageing in outdoor environment and soil burial

\begin{tabular}{clcc}
\hline Sample & Composition & \multicolumn{2}{c}{ Weight loss (\%) } \\
\cline { 3 - 4 } & & $\begin{array}{c}\text { Outdoor } \\
\text { environment }\end{array}$ & $\begin{array}{c}\text { Soil } \\
\text { burial }\end{array}$ \\
\hline 1 & $100 \mathrm{wt} \%$ VPLA & 3.0 & 13.2 \\
2 & $95 \mathrm{wt} \%$ VPLA + 5 wt $\%$ SA & 3.5 & 14.5 \\
3 & $90 \mathrm{wt} \%$ VPLA + 10 wt\% SA & 4.5 & 16.2 \\
4 & $85 \mathrm{wt} \%$ VPLA + 15 wt\% SA & 6.5 & 21.9 \\
5 & $80 \mathrm{wt} \%$ VPLA + 20 wt\% SA & 7.7 & 25.6 \\
6 & $100 \mathrm{wt} \%$ RPLA & 3.4 & 14.5 \\
5 & $95 \mathrm{wt} \%$ RPLA + 5 wt\% SA & 5.3 & 16.1 \\
8 & $90 \mathrm{wt} \%$ RPLA + 10 wt\% SA & 6.8 & 21.6 \\
9 & $85 \mathrm{wt} \%$ RPLA + 15 wt\% SA & 7.7 & 29.3 \\
10 & $80 \mathrm{wt} \%$ RPLA + 20 wt\% SA & 12.8 & 38.2 \\
\hline
\end{tabular}

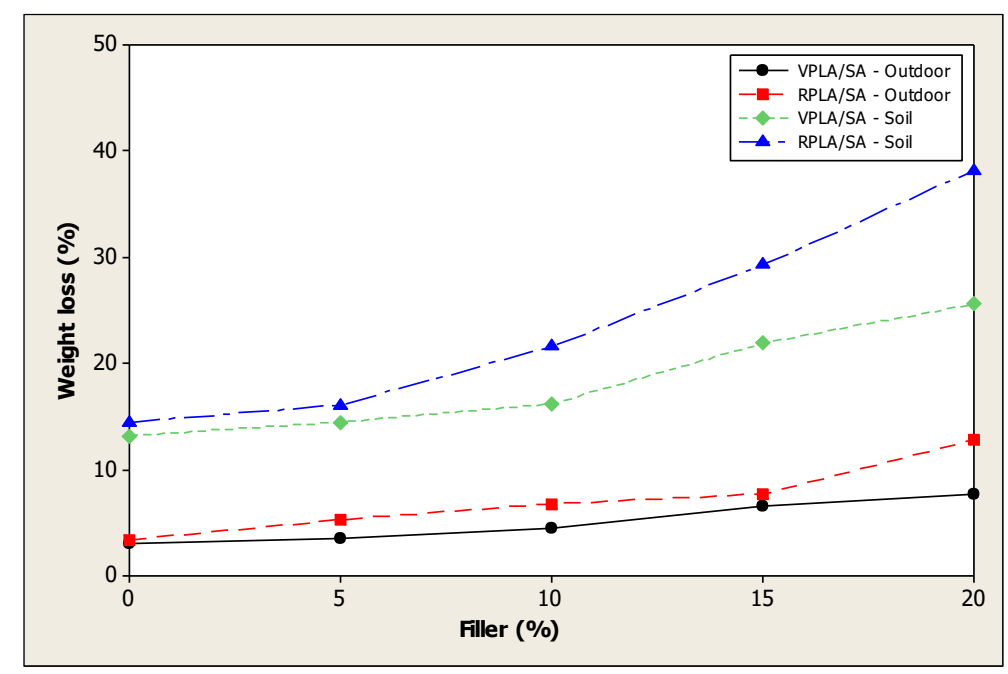

Fig 1: Plots of SA filler content versus weight loss.

While for RPLA/SA composites with $20 \mathrm{wt} \%$ of SA filler, the weight loss after ageing in outdoor environment and soil burial had increased to $12.8 \%$ and $38.2 \%$, respectively. The lowest weight loss exhibited in $100 \mathrm{wt} \%$ VPLA and $100 \mathrm{wt} \%$ RPLA was due to its low hygroscopic activity that was attributed to a slower rate of hydrolysis at lower temperatures and to the low degradation capacity of PLA microorganisms in composting [31]. When fillers were added to the PLA matrix, the interface between filler particles and matrix served as a leading path for the water molecules to penetrate the samples while simultaneously breaking the long polymer chain to low molecular weight. As the content of the filler increased, the interface surface was also increased and consequently accelerated the polymer chain scission and degradation process.

The results were noteworthy as they revealed that the degradation rates were more rapid in the soil burial as compared in the outdoor environment. The excessive volume of water in the soil introduced higher water diffusion into the composites, which consequently promoted active hydrolysis degradation of the composites. The presence of microorganisms in the soil would additionally enhance the degradation process of the composites. In contrast, when PLA/SA composites were exposed to the outdoor environment, it was known that UV irradiation, heat, and moisture from the atmosphere during ageing process had led to the deterioration in the polymer molecular chain via chain scission reactions through 
photolysis and hydrolysis degradations. The photodegradation and moisture penetration started at the exposed surface followed by propagation through the interior body.

It was also noticeable that the weight loss for RPLA/SA composites was higher as compared with VPLA/SA composites. It was well known that due to shear forces and thermal impact encountered during the processing, RPLA exhibited a shorter molecular chain with lower molecular weight [32]. The chain scissions during the processing were reported by Chavez-Montes et al. [33], in which the authors observed around 30\% to $40 \%$ of reductions in average molecular weight for virgin PLA after undergoing the single stage of injection moulding. The smaller molecular weight would intensively accelerate the degradation process upon ageing in outdoor environment and soil burial.

Table 3: Comparison of weight loss on various PLA composites

\begin{tabular}{|c|c|c|c|c|}
\hline No & Ageing environment & Composition & Weight Loss (\%) & References \\
\hline 1 & Soil Burial - 110 days & $\begin{array}{l}\text { PLA } \\
\text { PLA/15\% CNC-ZnO }\end{array}$ & $\begin{array}{c}9 \\
28\end{array}$ & {$[26]$} \\
\hline 2 & Soil Burial - 90 days & $\begin{array}{l}\text { PLA } \\
\text { PLA } / 25 \% \text { sisal fiber }\end{array}$ & $\begin{array}{l}1.26 \\
15.2\end{array}$ & {$[27]$} \\
\hline 3 & Soil Burial - 105 days & $\begin{array}{l}\text { PLA }<1 \% \\
\text { PLA } / 9 \% \text { starch } / 21 \% \text { wood floor } \\
\text { PLA } / 15 \% \text { starch } / 15 \% \text { wood floor } \\
\text { PLA } / 21 \% \text { starch } / 9 \% \text { wood floor }\end{array}$ & $\begin{array}{c}<1 \\
6 \\
9 \\
12\end{array}$ & {$[28]$} \\
\hline 4 & Soil Burial - 120 days & $\begin{array}{l}\text { PLA } \\
\text { PLA/starch }\end{array}$ & $\begin{array}{l}0.102 \\
27.11\end{array}$ & [29] \\
\hline 5 & Soil Burial - 18 days & $\begin{array}{l}\text { PLA } \\
\text { PLA/coir fiber }\end{array}$ & $\begin{array}{l}18.1 \\
22.6\end{array}$ & {$[34]$} \\
\hline 6 & $\begin{array}{l}\text { Outdoor environment - } 10 \\
\text { weeks ( } 70 \text { days) }\end{array}$ & $\begin{array}{l}100 \mathrm{wt} \% \text { VPLA } \\
\text { VPLA } / 20 \mathrm{wt} \% \mathrm{SA} \\
100 \mathrm{wt} \% \mathrm{RPLA} \\
\text { RPLA } / 20 \mathrm{wt} \% \mathrm{SA}\end{array}$ & $\begin{array}{c}3 \\
7.7 \\
3.4 \\
12.8\end{array}$ & Present work \\
\hline 7 & $\begin{array}{c}\text { Soil Burial - } 10 \text { weeks (70 } \\
\text { days) }\end{array}$ & $\begin{array}{l}100 \mathrm{wt} \% \text { VPLA } \\
\text { VPLA } / 20 \mathrm{wt} \% \mathrm{SA} \\
100 \mathrm{wt} \% \mathrm{RPLA} \\
\mathrm{RPLA} / 20 \mathrm{wt} \% \mathrm{SA}\end{array}$ & $\begin{array}{l}13.2 \\
25.6 \\
14.5 \\
38.2\end{array}$ & Present work \\
\hline
\end{tabular}

The comparison between degradation of various PLA composites from previous works and present works is listed in Table 3. There was not much information related to weight loss in the outdoor environment that was currently available. Similarly, the degradation of RPLA and RPLA composites was also rarely reported. In general, the findings from this work were consistent with the previous findings. The dissimilar percentage in mechanical properties reduction could be explained through the divergent variations in soil conditions such as temperature, humidity, and $\mathrm{pH}$ of the soil. The types of microorganisms in the soil also highly affected the degradation rate. The shorter degradation time of the PLA/SA composites obtained from this study have increased its potential to be used as food packaging material. 


\subsection{Surface Morphology}

The surface morphology was examined using SEM. Before ageing, the surfaces of the VPLA/SA composites and RPLA/SA composites were smooth. The SA fillers were evenly dispersed in the PLA matrix. After 10 weeks of ageing in outdoor weathering and soil burial, the surfaces were observed to be eroded with multiple formations of voids, cavities, cleavages, and grooves. It was also noted that the aged samples were more brittle and easily broken. These might be due to the recrystallisation of PLA/SA composites during ageing process.

The comparison of the surface morphology of VPLA/SA composites after ageing in outdoor environment and soil burial is shown in Fig. 2. As demonstrated in Fig. 2a and 2b, in both environments, VPLA did not show any significant macroscopic alternations on the surfaces as the surfaces were still compact and tight with the presence of minimum voids. This was due to its poor hydrophilic characteristic which had hindered the penetration of water [35]. The number of voids on soil burial samples was more discernible as compared to samples that aged in the outdoor environment.

When $5 \mathrm{wt} \%$ of SA fillers were added into the VPLA matrix, the number of voids increased and the size of the voids was enlarged (as seen in Fig. 2c and 2d). As the amount of SA fillers increased to $20 \mathrm{wt} \%$, the surfaces of VPLA/SA composites were seriously eroded with multiple formations of cavities, cleavages, and grooves as illustrated in Fig. $2 \mathrm{~g}$ and $2 \mathrm{~h}$. The observations on the surface morphologies were consistent with the weight loss findings.

A similar pattern was observed on RPLA/SA composites. As shown in Fig. 3a and 3b, after the ageing processes in outdoor environment and soil burial, numerous voids were present. The presence of SA fillers in the composites had accelerated the formations of voids and cavities. With the increase of SA fillers, the damages on surface morphologies were gradually expanded. As shown in Fig. 3c until 3h, the number and size of voids and cavities were increased with increasing of $\mathrm{wt} \%$ of SA fillers. The presence of voids and cavities indicated that the composites have degraded, and these explained the reductions in weight. Similarly, it was seen that the formations of voids and cavities were more significant on the samples that aged through soil burial as compared to the samples that aged under outdoor environment. In the soil burial degradation, the composites were subjected to hydrolysis degradation under the conditions of water and microorganisms while in the outdoor environment, degradation was induced through UV irradiation, photo-thermal factors, and moisture. The degradations from these resources produced ruptures in the molecular chain, reduced the interfacial adhesion between fillers and PLA matrix, and finally led to the disintegration and fragmentation of the composites.

\subsection{Thermogravimetric analysis (TGA)}

Thermal stabilities of VPLA/SA composites and RPLA/SA composites after ageing were evaluated through thermogravimetric analysis (TGA). The TGA curves for VPLA/SA composites and RPLA/SA composites are shown in Fig. 4. The curves clearly indicate that the composites had undergone a normal single-step thermal degradation process. 

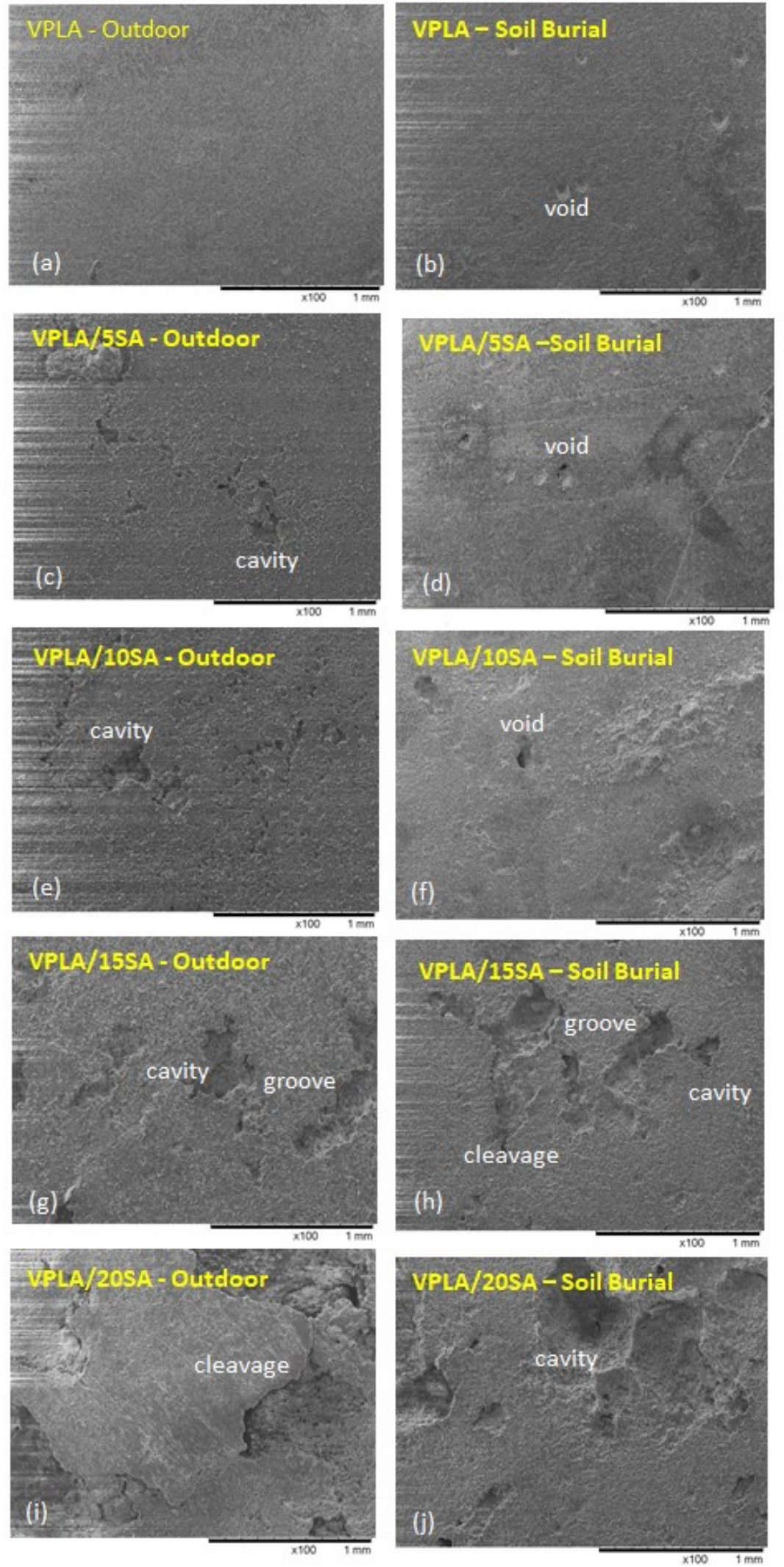

Fig. 2: Surface Morphologies of VPLA/SA composites with varying SA filler composition after 10 weeks of ageing in outdoor environment and soil burial (a-b) $0 \mathrm{wt} \%$, (c-d) $5 \mathrm{wt} \%$, (e-f) 10 $\mathrm{wt} \%$, (g-h) $15 \mathrm{wt} \%$, (i-j) $20 \mathrm{wt} \%$. 

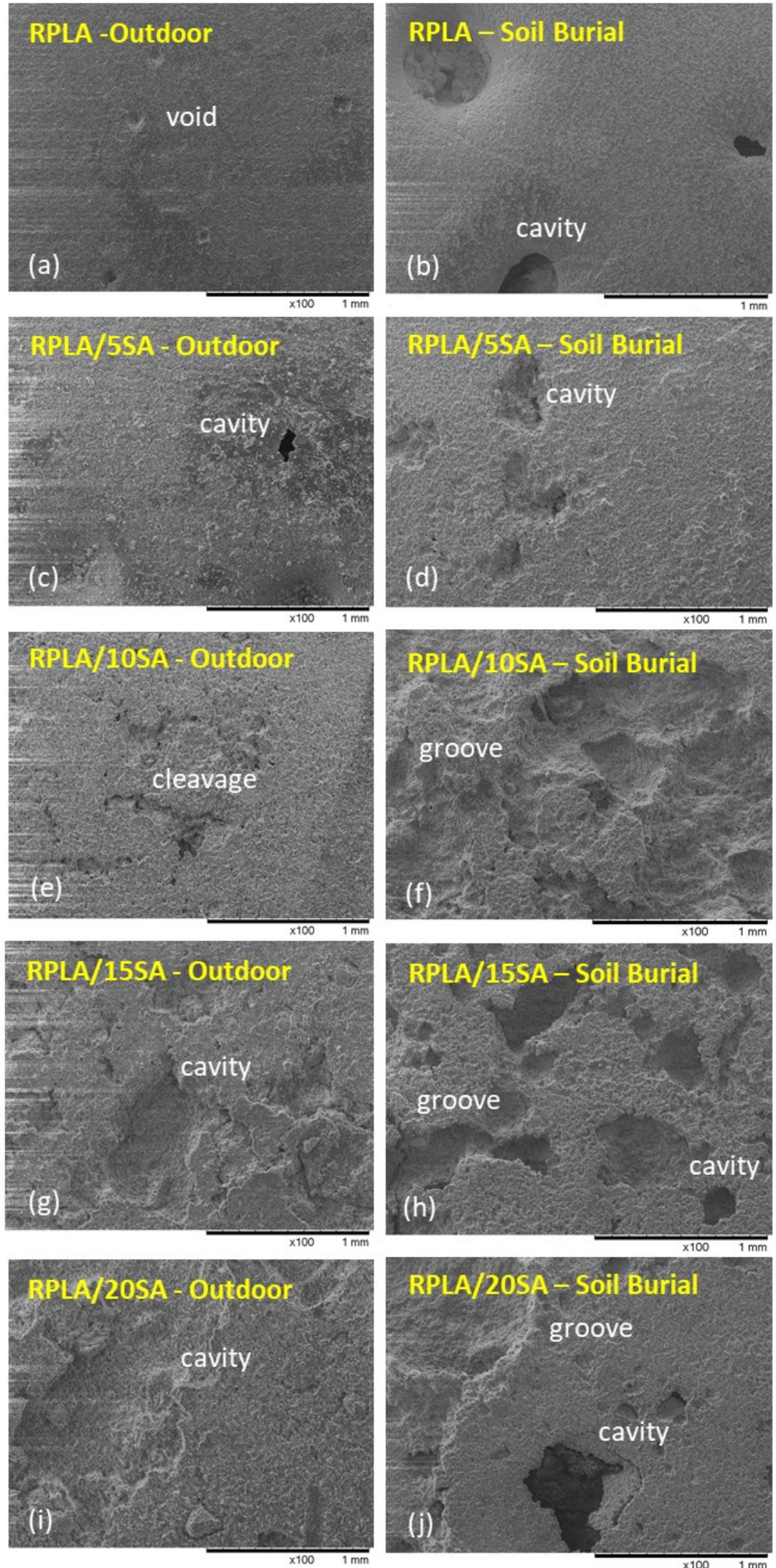

Fig. 3: Surface Morphologies of RPLA/SA composites with varying SA filler composition after 10 weeks of ageing in outdoor environment and soil burial (a-b) $0 \mathrm{wt} \%$, (c-d) $5 \mathrm{wt} \%$, (e-f) 10 wt $\%$, (g-h) $15 \mathrm{wt} \%$, (i-j) $20 \mathrm{wt} \%$. 

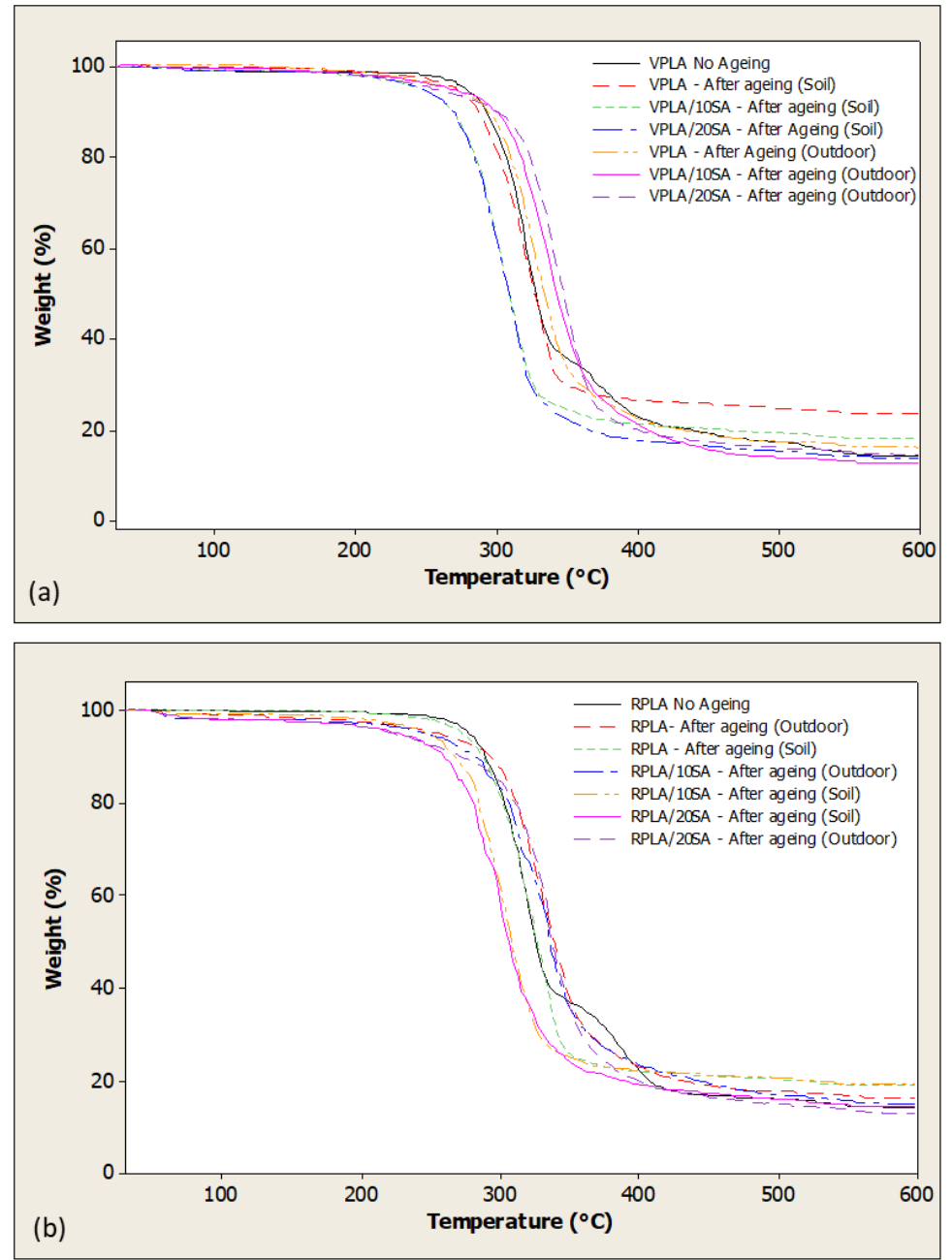

Fig. 4: Thermogravimetric curves of (a) VPLA/SA composites and (b) RPLA/SA composites.

Table 4 summarized the initial degradation temperature $\left(T_{i}\right)$ and maximum degradation temperature $\left(\mathrm{T}_{\max }\right)$ for VPLA/SA composites and RPLA/SA composites with the addition of $10 \mathrm{wt} \%$ and $20 \mathrm{wt} \%$ SA fillers after ageing in outdoor environment and soil burial. $T_{i}$ and $\mathrm{T}_{\max }$ for VPLA and RPLA before ageing were also included. Before ageing, the thermal degradations for VPLA and RPLA started around $290{ }^{\circ} \mathrm{C}$. A slight decrease in the initial degradation temperature for RPLA was seen. The observation was reasonable since RPLA experienced molecular weight reduction during reprocessing which naturally affected the onset of degradation temperatures. After ageing in outdoor environment, the initial degradation temperatures for VPLA, RPLA, and its composites were increased. An increase in $\mathrm{T}_{\mathrm{i}}$ had become more recognizable with the increment of $\mathrm{wt} \%$ of SA fillers. An increase in the degradation temperature was probably due to the increased crystallinity during photolysis and photodegradation. As noted by Lv et al. [28], during the degradation process, the crystallinity of the PLA composites was increased at the initial stages and decreased as degradation progressed. A similar observation was reported by Zuo et al. [29]. It was expected that the $T_{i}$ would be decreased with the extension of ageing time and the degradation rate would be rapidly augmented. 
Table 4: The initial and maximum degradation temperatures of (a) VPLA/SA composites and (b) RPLA/SA composites

\begin{tabular}{|c|c|c|c|c|c|}
\hline Composition & $\begin{array}{l}\mathbf{T}_{\mathrm{i}} \\
\left({ }^{\circ} \mathbf{C}\right)\end{array}$ & $\begin{array}{l}\mathbf{T}_{\max } \\
\left({ }^{\circ} \mathbf{C}\right)\end{array}$ & Composition & $\begin{array}{c}\mathbf{T}_{\mathbf{i}} \\
\left({ }^{\circ} \mathbf{C}\right)\end{array}$ & $\begin{array}{l}\mathbf{T}_{\max } \\
\left({ }^{\circ} \mathbf{C}\right)\end{array}$ \\
\hline VPLA No Ageing & 291 & 356 & RPLA No Ageing & 286 & 355 \\
\hline $\begin{array}{l}\text { VPLA - After ageing } \\
\text { (Outdoor) }\end{array}$ & 295 & 359 & $\begin{array}{l}\text { RPLA - After ageing } \\
\text { (Outdoor) }\end{array}$ & 296 & 370 \\
\hline $\begin{array}{l}\text { VPLA - After ageing } \\
\text { (Soil) }\end{array}$ & 288 & 347 & $\begin{array}{l}\text { RPLA - After ageing } \\
\text { (Soil) }\end{array}$ & 291 & 348 \\
\hline $\begin{array}{l}\text { VPLA/10SA - After ageing } \\
\text { (Outdoor) }\end{array}$ & 302 & 371 & $\begin{array}{l}\text { RPLA/10SA - After ageing } \\
\text { (Outdoor) }\end{array}$ & 287 & 372 \\
\hline $\begin{array}{l}\text { VPLA/10SA-After ageing } \\
\text { (Soil) }\end{array}$ & 270 & 335 & $\begin{array}{l}\text { RPLA/10SA - After Ageing } \\
\text { (Soil) }\end{array}$ & 270 & 335 \\
\hline $\begin{array}{l}\text { VPLA/20SA - After ageing } \\
\text { (Outdoor) }\end{array}$ & 313 & 370 & $\begin{array}{l}\text { RPLA/20SA - After ageing } \\
\text { (Outdoor) }\end{array}$ & 299 & 368 \\
\hline $\begin{array}{l}\text { VPLA/20SA - After ageing } \\
\text { (Soil) }\end{array}$ & 270 & 335 & $\begin{array}{l}\text { RPLA/20SA - After ageing } \\
\text { (Soil) }\end{array}$ & 263 & 340 \\
\hline
\end{tabular}

In contrast, the $T_{i}$ decreased after ageing through soil burial. The decrease in the $T_{i}$ was more significant with the addition of SA fillers in the PLA/SA composites. The results indicated that PLA/SA composites started and completely decomposed earlier when buried in soil. Elevated diffusion of water molecules accelerated the polymer chain scission. The addition of hydrophilic SA fillers caused a large amount of water molecules to penetrate the composites and provided a boost to the hydrolysis degradation process. Additionally, the presence of microorganisms in soil promoted the enzymatic degradation of the composites [36]. The extensive polymer chain scission during the degradation in soil burial consequently decreased the thermal stabilities of the PLA/SA composites.

\section{CONCLUSIONS}

This paper reported on the biodegradations of VPLA/SA composites and RPLA/SA composites upon ageing in outdoor environment and soil burial. SA was employed and added as a filler in VPLA matrix and RPLA matrix in the range of 0 to $20 \mathrm{wt} \%$. The results revealed that the degradations of PLA in outdoor environment and soil burial increased when SA filler was incorporated in the PLA matrix. The weight loss for $100 \mathrm{wt} \%$ VPLA and $100 \mathrm{wt} \%$ RPLA after 10 weeks of ageing in the outdoor environment were very low, at approximately $3 \%$ and $3.4 \%$, respectively. When SA filler was added to the PLA matrix, the weight loss was proportionally increased. The maximum weight loss was observed in PLA/SA composites with $20 \mathrm{wt} \%$ of SA filler. The weight loss for VPLA/SA composites was $7.7 \%$ while the weight loss for RPLA/SA composites was $12.8 \%$. In comparison, after 10 weeks of ageing in soil burial, the weight loss for $100 \mathrm{wt} \%$ VPLA and $100 \mathrm{wt} \%$ RPLA were $13.2 \%$ and $14.5 \%$ respectively. Similarly, when PLA was incorporated with SA filler, the degradation rate was found to be rapidly increased. The weight loss for VPLA/20 wt $\%$ SA was $25.6 \%$ whereas the weight loss for RPLA/20 wt $\%$ SA was $38.2 \%$.

In outdoor environment, UV irradiation, light, and heat resources from the sun, the hydrolysis degradation on the molecular chains were accomplished through photocleavage, photolysis, and photooxidation. In contrast, soil burial degradation occurred through the hydrolysis of water molecules on the ester group along the backbone of the polymer chain and enzymatic degradation produced by microorganisms in the soil. The findings proved that the degradation rate of soil burial is higher as compared with photolysis degradation in outdoor environment. 
In conclusion, it can also be concluded that the RPLA/SA composites exhibited higher degradation rates than VPLA/SA composites. Due to the shear forces and thermal impact encountered during the processing, VPLA exhibited shorter molecular chain with lower molecular weight which consequently catalysed the degradation process to take place. The shortening of the degradation time of the PLA/SA composites may provide a bright potential as an essential alternative for packaging materials.

\section{ACKNOWLEDGEMENT}

This research is supported by the Faculty of Mechanical Engineering and Faculty of Chemical Engineering, Universiti Teknologi MARA, Cawangan Pulau Pinang.

\section{REFERENCES}

[1] Ingrao C, Tricase C, Cholewa-Wójcik A, Kawecka A, Rana R, Siracusa V. (2017) Polylactic acid trays for fresh-food packaging: A carbon footprint assessment. Science of the Total Environment, 537:385-398.

[2] Hopewell J, Dvorak R, Kosior E. (2009) Plastics recycling: challenges and opportunities. Philosophical Transactions of the Royal Society B, 364:2115-26. https://doi.org/10.1098/rstb.2008.0311

[3] Wan L, Li C, Sun C, Zhou S, Zhang Y. (2019) Conceiving a feasible degradation model of polylactic acid-based composites through hydrolysis study to polylactic acid/wood flour/polymethyl methacrylate. Composite Science and Technology 181:107675. https://doi.org/10.1016/j.compscitech.2019.06.002

[4] Farah S, Anderson DG, Langer R. (2016) Physical and mechanical properties of PLA, and their functions in widespread applications - A comprehensive review. Advanced Drug Delivery Reviews, 107:367-392. https://doi.org/10.1016/j.addr.2016.06.012

[5] Silva D, Kaduri M, Poley M, Adir O, Krinsky N, Shainsky-Roitman J, Schroedera A. (2018) Biocompatibility, biodegradation and excretion of polylactic acid (PLA) in medical implants and theranostic systems. Chemical Engineering Journal, 340:9-14. https://doi.org/10.1016/j.cej.2018.01.010

[6] Tokiwa Y, Calabia CP, Ugwu CU, Aiba S. (2009) Biodegradability of plastics. International Journal of Molecular Sciencee, 10:3722-3742. doi:10.3390/ijms10093722

[7] Porfyris A, Vasilakos S, Zotiadis C, Papaspyrides C, Moser K, Vander Schueren L, Buyle G, Pavlidou S, Vouyiouka S. (2018) Accelerated ageing and hydrolytic stabilization of poly(lactic acid) (PLA) under humidity and temperature conditioning. Polymer Testing 68:315-332. https://doi.org/10.1016/j.polymertesting.2018.04.018

[8] Kaynak C, Sar1 B. (2016) Accelerated weathering performance of polylactide and its montmorillonite nanocomposite. Applied Clay Science 121:86-94. https://doi.org/10.1016/j.clay.2015.12.025

[9] Bocchini S, Frache A. (2013) Comparative study of filler influence on polylactide photooxidation. Express Polymer Letters, 7:431-442.

DOI: 10.3144/expresspolymlett.2013.40

[10] Risyon NP, Othman SH, Kadir Basha R, Talib RA. (2020) Characterization of polylactic acid/halloysite nanotubes bionanocomposite films for food packaging. Food Packaging and Shelf Life, 23:100450.

[11] Ahmed J, Mulla M, Jacob H, Luciano G, Bini TB, Almusallam A. (2019) Polylactide/poly(Ecaproplactone)/zin oxide/clove essential oil composite antimicrobial films for scrambled egg packaging. Food Packaging and Shelf Life, 21:100355. https://doi.org/10.1016/j.fpsl.2019.100355

[12] Chen C, Xu Z, Ma Y, Liu J, Zhang Q, Tang Z, Fu K, Yang F, Xie J. (2018) Properties, vapourphase antimicrobial and antioxidant activities of active poly(vinyl alcohol) packaging films incorporated with clove oil. Food Control, 88:105-112. https://doi.org/10.1016/j.foodcont.2017.12.039 
[13] Gavril GL, Wrona M, Bertella A, Świeca M, Râpă M, Salafranca J, Nerín C. (2019) Influence of medicinal and aromatic plants into risk assessment of a new bioactive packaging based on polylactic acid (PLA). Food and Chemical Toxicology, 132:110662. https://doi.org/10.1016/j.fct.2019.110662

[14] Sivakanthan S, Rajendran S, Gamage A, Madhujith T, Mani S. (2020) Antioxidant and antimicrobial applications of biopolymers: A review. Food Research International, 126:109327. https://doi.org/10.1016/j.foodres.2020.109327

[15] Rehman A, Jafari SM, Aadil RM, Assadpour E, Randhawa MA, Mahmood S. (2020) Development of active food packaging via incorporation of biopolymeric nanocarriers containing essential oils. Trends in Food Science \& Technology, 101:106-121. https://doi.org/10.1016/j.tifs.2020.05.001

[16] Hamad K, Kaseem M, Deri F. (2010) Rheological and mechanical properties of poly(lactic acid)/polystyrene polymer blend. Polymer Bulletin 65:509-519. DOI 10.1007/s00289-0100354-2

[17] Murariu M, Dubois P. (2016) PLA composites: From production to properties. Advanced Drug Delivery Reviews, 107:17-46. http://dx.doi.org/10.1016/j.addr.2016.04.003

[18] Zhang L, Huang C, Xu Y, Huang H, Zhoa H, Wang J, Wang S. (2020) Synthesis and characterization of antibacterial polylactic acid film incorporated with cinnamaldehyde inclusions for fruit packaging. International Journal of Biological Macromolecules, 164:45474555. http://doi.org/10.1016/j.ijbiomac.2020.09.065

[19] Cui R, Jiang K, Yuan M, Cao J, Li L, Tang Z, Qin Y. (2020) Antimicrobial film based on polylactic acid and carbon nanotube for controlled cinnamaldehyde release. Journal of Materials Research and Technology, 9(5):10130-10138. https://doi.org/10.1016/j.jmrt.2020.07.016

[20] Techawinyutham L, Siengchin S, Dangtungee R, Parameswaranpillai J. (2019) Influence of accelerated weathering on the thermo-mechanical, antibacterial, and rheological properties of polylactic acid incorporated with porous silica-containing varying amount of capsicum oleoresin. Composites Part B, 175:107108. https://doi.org/10.1016/j.compositesb.2019.107108

[21] Varsavas SD, Kaynak C. (2018) Weathering degradation performance of PLA and its glass fiber reinforced composite. Material Today Communications, 15:344-353. https://doi.org/10.1016/j.mtcomm.2017.11.008

[22] Fathima PE, Panda SK, Ashraf PM, Varghese TO, Bindu J. (2018) Polylactic acid/chitosan films for packaging of Indian white prawn (Fenneropenaeus indicus). International Journal of Biological Macromolecules, 117:1002-1010. https://doi.org/10.1016/j.ijbiomac.2018.05.214

[23] Hadidi M, Pouramin S, Adinepour F, Haghani S, Japari SM. (2020) Chitosan nanoparticles loaded with clove essential oil: Characterization, antioxidant and antibacterial activities. Carbohydrate Polymers, 236:116075. https://doi.org/10.1016/j.carbpol.2020.116075

[24] Han W, Ren J, Xuan H, Ge L. (2018) Controllable degradation rates, antibacterial, free-standing and highly transparent films based on polylactic acid and chitosan. Colloids and Surfaces A 541:128-136. https://doi.org/10.1016/j.colsurfa.2018.01.022

[25] Vasile C, Pamfil D, Râpă M, Darie-Niţă RN, Mitelut AC, Popa EE, Popescu PA, Draghici MC, Popa ME. (2018) Study of the soil burial degradation of some PLA/CS biocomposites, Composites Part B 142:251-262. https://doi.org/10.1016/j.compositesb.2018.01.026

[26] Wang YY, Yu HY, Yang L, Abdalkarim SYH, Chen WL. (2019) Enhancing long-term biodegradability and UV-shielding performances of transparent polylactic acid nanocomposite films by adding cellulose nanocrystal-zinc oxide hybrids. International Journal of Biological Macromolecules, 141:893-905. https://doi.org/10.1016/j.ijbiomac.2019.09.062

[27] Rajesh G, Prasad AVR, Gupta AVSSKS. (2019) Soil degradation characteristics of short sisal/PLA composites. Materials Today: Proceedings 18:1-7. https://doi.org/10.1016/j.matpr.2019.06.270

[28] Lv S, Zhang Y, Gu J, Tan H. (2017) Biodegradation behaviour and modelling of soil burial effect on degradation rate of PLA blended with starch and wood flour. Colloids and Surfaces B: Biointerfaces, 159:800-808. https://doi.org/10.1016/j.colsurfb.2017.08.056 
[29] Zuo YF, Gu J, Qiao Z, Tan H, Cao J, Zhang Y. (2015) Effects of dry method esterification of starch on the degradation characteristics of starch/polylactic acid composites. International Journal of Biological Macromolecules, 72:391-402. https://doi.org/10.1016/j.ijbiomac.2014.08.038

[30] Mohammad ST, Al-Kayiem HH, Aurybi MA, Khlief AK. (2020) Measurement of global and direct normal solar energy radiation in Seri Iskandar and comparison with other cities of Malaysia. Case Studies in Thermal Engineering, 18:100591. https://doi.org/10.1016/j.csite.2020.100591

[31] Salazar-Sánchez MR, Campo-Erazo SD, Villada-Castillo HS, Solanilla-Duque JF. (2019) Structural changes of cassava starch and polylactic acid films submitted to biodegradation process. International Journal of Biological Macromolecules, 129:442-447. https://doi.org/10.1016/j.ijbiomac.2019.01.187

[32] Zhao P, Rao C, Gu F, Sharmin N, Fu J. (2018) Close-looped recycling of polylactic acid used in 3D printing: An experimental investigation and life cycle assessment. Journal of Cleaner Production, 197:1046-1055. https://doi.org/10.1016/j.jclepro.2018.06.275

[33] Chavez-Montes WM, Gonzalez-Sanchez G, Lopez-Martinez EI, Lira-Gomez P, BallinasCasarrubias L, Flores-Gallardo S. (2015) Effect of artificial weathering on PLA/Nanocomposite molecular weight distribution. Polymers 7:760-776. https://doi.org/10.3390/polym7040760

[34] Dong Y, Ghataura A, Takagi H, Haroosh HJ, Nakagaito AN, Lau KT. (2014) Polylactic acid (PLA) biocomposites reinforced with coir fibres: Evaluation of mechanical performance and multifunctional properties. Composites: Part A, 63:76-84. http://dx.doi.org/10.1016/j.compositesa.2014.04.003

[35] Qi Y, Ma HL, Du ZH, Yang B, Wu J, Wang R, Zhang ZQ. (2019) Hydrophilic and antibacterial modification of poly(lactic acid) films by $\gamma$-ray irradiation. ACS Omega, 4:21439-21445. http://pubs.acs.org/journal/acsodf

[36] Bahl S, Dolma J, Singh JJ, Sehgal S (2021). Biodegradation of plastics: A state of the art review. Materials Today: Proceedings 39:31-34. https://doi.org/10.1016/j.matpr.2020.06.096 